\title{
Students' Self-Confidence and Its Impacts on Their Learning Process
}

\section{Abstract}

\author{
Omidullah Akbari \\ English Language and Literature Department \\ Kandahar University \\ Kandahar, Afghanistan \\ E-mail: akbariomidullah@gmail.com \\ Javed Sahibzada \\ Senior Assistant Professor \\ English Language and Literature Department \\ Kandahar University \\ Kandahar, Afghanistan \\ E-mail: sahibzada.javed@,gmail.com
}

\begin{abstract}
The purpose of this study was to measure students' self-confidence and finds its impacts on their learning process at Kandahar University. The study is descriptive in nature where quantitative questionnaire is used to collect data through stratified sampling from 1375 male and female students. The findings revealed only some of the students were low self-confident and most students were highly self-confident. In addition, students' self-confidence effected their learning in areas of students' participation, in seeking goal, developing interest in lessons, in decreasing students' anxiety, they are being comfortable with their instructors and classmates and also in sharing their opinions related to lessons in class.
\end{abstract}

Keywords: Impacts, Learning, Measuring, Process, Self-Confidence.

\section{Introduction}

Competence knowledge and performance are interrelated concept and they are the key success for individual in their career. Due to the lack of each one can face many challenges their lives. Students with the lack of any of these may face various challenges in achieving intended outcomes which have been set out by their respected institutions or the goals they have for themselves. The lack of self-confidence in students may not only create problem for students but for institutions areas of thereof and in effective implementation of curriculum.

Most of the current crisis in the educational system is due to low self-confidence that leaded a number of students having lack of enough participation and unsatisfactory progress after much time spends in the class. As Norman \& Hyland (2003) state confidence is a factor in learning which can have its effects on students' participation and progress. Self-confidence is very necessary for a student to take risks and engage in the learning activities and those who have self-confidence they are assured of their abilities and are setting goals for themselves and work hard to achieve their goals without worrying about the outcomes (Kanza, 2016).

Mutluer (2006) \& Yavuzer (I998) (as cited in Sara, Avcu \& Isiklar 2010) assert that human is born with selfconfidence but it is changeable during the age Students' self-confidence can be lowered due to students' anxiety, self-insecurity, fear and feeling of being apart from the society (Rubio, 2007). According to Benabou \& Tirole (2002), self-confidence is very effective in motivating humans and can lead to changing human's behavior. The self-confidence should be considered as the quality of a student in which the student feels him/herself assured of successfully performing of different activities in the class and out of the class for the purpose of learning. However, the impact of self-confidence in learning process the researcher means that how students' learning varies when students experience either high self-confidence or low self-confidence.

Functionally, learning is a set of changes which are brought to the behavior of a person resulting from the experiences done by a human (Houwer, Holmes \& Moors, 2013). Taylor \& Mackenney (2008, p.263) defines learning as a permanent change in the behavior of an individual. They further define learning as the act of engaging students in activities and letting them get knowledge through their sharing experiences or getting information from the teacher.

Self-confidence is defined as the believe or trust that a student has in performing something successfully (Kanza, 2016). According to Perkins (2018) self-confidence is related to success, achievements in education, conciliation, and a persons' well-being, among other things and self-efficacy, self-esteem, and self-compassion are the three factors which can affect the level of self-confidence of any individual. 


\section{Statement of the Problem}

Although self-confidence enhances a student's motivation in learning process and its impact is explained thereof. There are various challenges exists for students with lower self-confidence. For instance, Benabou \& Tirole (2002) point out that there is still one big challenge that students are having as their vulnerability in learning is the lack of self-confidence which can adversely affect the learning of any students. According to Rubio (2007) due to low self-confidence many psychological barriers such as feeling of in secureness, fearfulness, having anxiety, and feeling yourself apart from the society are possible barriers that may arise for a student during the class which can adversely affects the performance of individual. They can consequently be leading an individual being distracted from the learning process. Based on personal experiences of the researchers, it has been observed that most of students at Kandahar University having poor participation in classes. Since the participation is closely related to selfconfidence, this is the major concern that students' poor performance maybe due to the lack of self-confidence which can consequently affect their vulnerability in learning process.

According to Benabou \& Tirole (2002) self-confidence has its effect on motivation and can change humans' behavior and is considered as a factor for students' problem-solving skill at the university. In addition to that Palavan (2017) states that students' lack of self-confidence can cause for students' lack of motivation which in result can cause education become compulsory and make student show negative attitude toward learning. These are the key causes and ins pirations for conducting the research. Because if students' poor performance continues, the intended outcomes set out the respected departments and effective curriculum is not possible to be achieved. Tunçel (2015) suggest language teachers to develop their students' selfconfidence and avoid those behaviors which lower students' self-confidence.

\section{The Significances of the Study}

A large body of current literatures related to students' self-confidence shows that in many counties many researchers, specially: Sar, Avcu \& Isiklar (2010) in Turkey, Verma \& Kumari (2016) in Ludhiana (Punjab), Fatma (20I5) in India, Karimi \& Saadatmand (2014) in Asfahan, Al-Hebaish (2012) in Saudi and Gardner, Dukes \& Discenza (1993) in San Francisco has considered self-confidence as an important factor for enhancing students' learning and many efforts has been taken for developing students' self-confidence in learning while less attention is paid to this issue in Afghan context especially, Kandahar university. There is need for measuring students' self-confidence and its impact on their learning process to fill somehow the existed gap. This study will add to the existing literature of students' self-confidence through conducting a study related to students' self-confidence with a different population in different research cite. In addition to that, this study will benefit the ministry of higher education, department of educational psychology, department of pedagogy, university curriculum designers, university policy makers, university teachers, and university students in identifying the causes of their lower performance and possible solutions to exist in effective curriculum implementation. Moreover, this study will also help school teachers and students and other related organizations who deal and care with students' self-confidence. This study will give a clear picture of the Kandahar University students' self-confidence level and its effects in learning process to the thereof sectors. The purpose of this study is to measure students' self-confidence on learning and find its impacts on learning process.

\section{Research Objectives}

The current study aims to identify the level of students' self-confidence in learning at Kandahar University. Besides that, finding out how the self-confidence had impacts on students' learning at Kandahar University is another key aims direct the study toward its findings.

\section{Research Questions}

- What is the level of students' self-confidence in learning at Kandahar University?

- What are the impacts of students' self- confidence on their learning process at Kandahar University?

\section{Review of the Literature}

This part of the study explores previous studies related to students' self-confidence. It explores the level of students' selfconfidence on learning and the impacts of students' self-confidence on their learning and scholar's opinion about self-confidence and its impact has been documented.

\section{I Students' Self-confidence Level}

A large body of literature is related to measuring students' self-confidence in learning. Tripathy \& Srivastava (2012) believe that self-confidence is an attitude and students with self-confident believe on their abilities, they are goal-directed, they believe that they will reach their goals and expectations. Self-confidence is not the same in all areas of a person's life. It is possible that an individual be very confident in one area of life and less confident in some other areas of life.

Mahyuddin et.al (2006) has investigated the relationship between students' self-efficacy and their English language achievement on I,I46 students and has found out that more than a half of the students were highly self-confident and less than 
the half number of students were low self-confident. On the other hand, Atherton (2015) measured confidence of male and female students in open access enabling courses and found that male students were not having any significant lack of confidence in regard to the assessment tasks that involved the quizzes and the final exam. On the other hand, his study revealed a significant lack of confidence among female in regard to all areas, including course satisfaction, mid-semester test, their relation with their professors, taking pre-requisite textbooks and materials, quiz performances and their performances in final exam.

Similarly, Sar, Avcu, \& Isiklar (2010) studied undergraduate students' level of self-confidence in and found some important differences at the level of students' self-confidence based on students' genders and departments. However, Verma $\&$ Kumari (2016) investigated the effects of self-confidence on academic achievement of elementary school students and did not find any significant difference in students' self-confidence in term of gender. Moreover, Tripathy \& Srivastava (20I2) studied the effects of academic achievements on the level of self-confidence also found no difference in students' self-confidence in terms of students' gender but the researchers found that there was a relationship between students' academic achievements and selfconfidence. The study further revealed that students with higher academic achievement had a higher level of self-confidence and students with lower academic achievements had a lower level of self-confidence.

In addition to that, Nurmi, Hannula, Maijala, \& Pehkonen (2003) have studied pupils' self-confidence in mathematics. They found that the weakest student had the lowest self-confidence and their study also revealed that students' self-confidence was varying among male and female students. Their study showed that boys had remarkably higher selfconfidence than girls and the study has also examined students' self-confidence on most skillful students for the second time to see either the finding is the same or not and found that boys were noticeably more confident in compare to girls.

Moreover, Fatma (2015) have investigated self-confidence of adolescents in relation to their gender, locality and academic achievement. She found that male had higher self-confidence in comparison to females. Her study rejected her proposed hypothesis of the study that said both male and female are having the same level of self-confidence. On the other hand, her study also found that there was no significant difference between the learning outcome of both male and female students. The study further found that the level of self-confidence among the rural students was higher in comparison to urban students. However, she also found the academic achievements of the urban students were higher than the rural students'.

Some other researchers have explored the level of students' self-confidence in learning in regard to some other factors. For instance, Laird (2005) has studied diversity as the theoretical framework in their study and an influencing factor for students' self-confidence and studying college students' experiences with diversity and their effects on their self-confidence, social agency and disposition toward critical thinking. The study found that students with different experiences, different courses, having a positive relationship with their different partners were having a higher level of self-confidence. The study further found diversity as an important component for college students' education.

In addition to that Clark (1994) has explored the adolescents in post-divorce and always-married students. He found that students who live away from their parents for short or long time, or who have parents who do not show much interest in them are lacking the self-confidence. The researcher further claimed that the family factor can be effective in the development of self-confidence among students.

Palvan (2017) explored the impact of drama education on the self-confidence and problem-solving skills of students at primary school education and his finding indicated that the level of students' self-confidence and problem-solving skills were low before the drama education and after the drama education. The study further revealed that students' self-confidence and problem-solving skills levels were improved through the use of drama education and the researcher suggest teachers to use drama education in their classes.

On the other hand, Colbeck, Cabrera, \& Terenzini (200I) have studied learning professional confidence, linking teaching practices, students' self-perceptions, and gender. They have found that teaching practices are an influencing factor for students' self-confidence rather than students' background characteristics. The study conducted by Still, Pulford \& Sohal (2006) to explore student's self-confidence on academic abilities by measuring individual's learning profile. Their findings revealed that students' carefulness, honesty, and the attitude of expecting everything to be perfect are the strongest factors influencing students' academic confidence and had affected students' confidence.

\subsection{Impacts of Students' Self-Confidence on Their Learning Process}

A large body of literature is concerned to the impacts of students' self-confidence in learning process. Norman \& Hyland (2003) have studied the role of confidence in lifelong learning. They have found students' confidence as a barrier to students' learning which a factor is affecting students' participation and progress. The study further shows that students' level of self-confidence can be affected by any individual student and his or her teachers, partners, temporary adviser and workplace supervisors. Similarly, Rubio (2007) studied self-esteem and foreign language learning and found that anxiety, self-insecurity, fear and feeling yourself apart from the society are a number of psychological situations which are possible to be arisen in learning due to low self-confidence. 
Tuncel (2015) have studied the relationship between self-confidence and learning Turkish as a foreign language. The study found a relation between self-confidence and learning and the study showed that high self-confidence affected the learning positively and low self-confidence effected learning negatively. Similarly, in Cologne Laboratory, Fischer \& Sliwka (2018) through experimentally studying the causal effects of external factors based changes on the motivation for learning, found that confidence in someone's ability to learn stimulates someone for learning. The finding of this study indicated that higher confidence in the level of prior knowledge causes students with low levels of knowledge to work and care more.

In addition, Verma et al. (2016) have studied the effects of self-confidence on academic achievement of elementary school students. They found out that self-confidence is affecting the academic achievement of students based on the low and high level of students' self-confidence and their study showed significant differences in academic achievements of students' either having low or high self-confidence. Fatma (2015) has studied self-confidence of adolescents in relation to their gender, locality and academic achievement. Her findings show that there is a correlation between the academic achievements and the self-confidence of the students. Her finding suggests that there is relationship between students' self-confidence and learning outcomes because her findings shows that with the increase of self-confidence the academic achievement also increased.

Karimi \& Saadatmand (20I4) conducted a study to find out the relationship between self-confidence with academic achievement based on academic motivation. Their study revealed that there was a relation between the academic achievement in both self-confidence and educational motivation. The researcher found that self-confident students gained success in learning. The researcher further states, the positive feedbacks, positive motivation, and school solving students' problems raises students' confidence. The link learning and motivation is also suggested by (Afzal, Ali, Khan \& Hamid, 2010) who state the intrinsic motivation and extrinsic motivation are having positive impacts on students' learning.

The study conducted by Yashima, Zenuk-Nishide, \& Shimizu (2004) to explore the influence of attitudes and effect on willingness to communicate and second language communication. Their findings revealed that self-confidence is a very important factor which can lead to students' willingness to participate in oral activities in the classroom. Moreover, Al-Hebaish (2012) studied the correlation between general self-confidence and academic achievement in the oral presentation course. He found that students' academic achievement can be affected by the self-confidence. Since, the study revealed that students with high level of self-confidence scored higher in oral test and students with low level of self-confidence scored lesser and showed lack of interest in having higher oral performance.

A similar study, by Tridinanti (2018) investigating the correlation between speaking anxiety, self-confidence, and speaking achievement of undergraduate EFL students. The findings of this study show that self-confidence is playing the role of a significant predictor for students' performance rather than anxiety. The study revealed that students having self-confidence had higher achievements and recommended students to improve self-confidence for having better performance. Jones (200I) conducted a study on academic self-confidence. His finding shows a correlation between the academic self-confidence and achievement striving. His showed that academic self-confidence will have a high, positive correlational achievement striving. His findings furtherly showed that students who were confident at school were also confident in goal seeking and were very focused for achievements. Similarly, Verma \& Kumari (2016) studied the effect of self-confidence on academic achievement of children at elementary stage. Their result indicated that there were some differences in the academic achievement of students in relation to their low and high level of self-confidence.

A study of Students' self-confidence and learning through dialogues in a Net-Based environment by Jakobsson (2006), revealed that a significant relationship exists between students' self-confidence and succession in their studies. And the study further showed that students with good self-confidence experienced working through the internet full of inspiration and they felt they had worked harder than the others.

Sihotang, Setiawan, \& Saragi (2017) investigated the effects of learning strategies and confidence on student's learning outcomes. They have found that student's learning outcomes were related to learning strategy and self-confidence. Their study further revealed found that students who had high confidence had better learning outcomes in comparison to students who had low self-confidence.

In the field of technology, a study conducted by Gardner, Dukes \& Discenza (1993) in studying computer use, selfconfidence, and attitudes with a causal analysis of computers in human behavior. They have found that that the use of computer can give an individual a high level of computer self-confidence. The researchers further found that the negative experiences of computer in early life can cause negative attitudes toward computer. However, Puzziferro (2008) explored online technologies self-efficacy and self-regulated learning as predictors of final grade and satisfaction in college found that online technologies selfconfidence is not related to students' performance.

Busch (1995) also studied gender differences in self-efficacy and attitudes toward computers. The study found gender differences in the level of self-confidence related to the completion of complex tasks in both word processing and spreadsheet software but there were no gender differences related to simple computer tasks. Their study further showed that females had fewer computer experiences in-compare to males since males were encouraged more to the use of computer and had more experiences in computer games. 
Pajares \& Johnson (1994) have investigated confidence and competence in writing and thy found the existence of a relationship between self-efficacy and performance and revealed that writing uneasiness was negatively affected by selfconfidence. Arango (2015) studied students' self-confidence as a way to improve English oral production. His findings suggested showed that there is a relation between students' low self-confidence and oral production in classroom. And the researcher had a theoretical framework of three domains of learning: Cognitive, Affective and Psychomotor domains. In the study, the researcher used a strategy in the entire lesson plans and an oral project called, "building self-confidence". Through implementing this strategy tenth-grade students' self-confidence increased. As a result of their study students become aware of their abilities and were less reluctant to speak in the class and they were motivated to participate in the class.

Bauman (2012) has investigated self-esteem as a part of self-confidence in performing any activity and explored the importance of self-esteem in learning and behavior of children. He has found that there was no negative effect of self-confidence on students' learning and motivation. But oppositely the researcher found self-confidence as an important factor which influences students' motivation, learning, and behavior. Furthermore, Mahyuddin et.al (2006) investigating the relationship between students' self-efficacy and their English language achievement showed that students' trust on their ability or selfconfidence is an effective factor on students' learning. Similarly, Chemers, Hu, \& Garcia (200I) studied the effects of academic self-efficacy and optimism on students' academic performance, stress, health, and commitment found that academic selfconfidence is related to students' performance and self-adjustment. They have suggested that it can affect students' performances directly and indirectly. Wright (2009) has studied Building Self-confidence with Encouraging Words. Their study indicated that that less confident student are experiencing fearfulness, being pessimist, having no vision of life and are feeling insecure and live to make others happy rather than themselves. whereas high self-confident students are ambitious and want more from life, are goal oriented, and have a real vision of life (seeing themselves in a better circumstance in life), and are attractive and open to others.

\section{Research Methodology \\ 7.I Research Types and Sampling Method}

The study is descriptive in nature and quantitative questionnaire is used to measures self -confidence of the I375 male and female in all level and different grade. They were selected through use of Stratified random sampling method from those faculties at Kandahar University whose self-confidence can be observed or engaged.

\subsection{Data Collection Procedures}

In the first phase of the study, students of different grades from six faculties namely, from Education that had total 1900 students 320 students were selected as samples, Literature faculty with total 600 from which 235 were sample, in Law and Political science had total 480 students from which selected samples were 2I4, in faculty Journalism that had from total 380 selected samples wereI9I, the faculty of Sharia and Law from total 500 selected samples were 2I8, and from total 400 population in Public Administration and PolicyI97 samples were selected. They were randomly selected so that everyone has an equal chance to be selected as the participant of the study (Creswell, 2012). In order to ensure the real sample size with the accuracy of 0.5, the survey table of Krejcie and Morgan is used in thereof sampling method. It is due to the number of students in all faculties were not equal so the researchers have used the thereof sample size.

As the present study, was conducted at the end of the academic year so students of all grades including freshmen had gotten enough experience of their self-confidence in the university and were able to provide the necessary data for the present study.

\subsection{Research Instrument}

The main instrument in this study is a questionnaire. The questionnaire is designed in three parts. The first part is about the demographic information of participants', the second part is for measuring students' self-confidence in learning process and consists fifteen items and each item has a choice of five scales such as: I. Not Confident at all, 2. Less confident, 3. Confident, 4. More Confident and 5. Extremely Confident so that any participants can show the level of his or her confidence in performing several task or activities inside the class and out of the class related to learning. Items for the second part are adopted from Paul Sander and Lalage Sanders" "Academic Confidence Scale ACS" "Measuring Confidence in Academic Study" (Sander \& Sanders, 2003). The adopted ACS was already tested for reliability through asking psychology students for two times to complete the questionnaire (Sander \& Sanders, et.al). The third part of the questionnaire is considered with the impacts of self-confidence in students' learning process and has twelve items each of who are having five choice of Linkert scale I. Strongly disagree, 2. Disagree, 3. Undecided, 4. Agree and 5. Strongly agree. The items for this part are drawn from the review of previews literature and are adapted from the ACS (Sander \& Sanders, 2003). The designed instrument was taking around eight minutes to be answered. The collected data was analyzed with IBM SPSS Statistics $20^{\text {th }}$ version and frequency and percentage and Percentage is presented in table and graphs. 


\section{Findings}

The data was collected to find out the students' self-confidence and its impact of on leering process at Kandahar and the collected data was analyzed through SPSS 24 version for frequency and percentage that presented in tables.

Table I. Demographics Data

\begin{tabular}{|c|c|c|c|}
\hline & Characteristics & Frequency & Percent \\
\hline \multirow{3}{*}{ Gender } & Male & 1259 & 91.6 \\
\hline & Female & II6 & 8.4 \\
\hline & Total & $\mathrm{I} 375$ & 100.0 \\
\hline \multirow{7}{*}{ Faculties } & Education & 320 & 23.3 \\
\hline & Literature & 235 & I7.I \\
\hline & Law and Politics & $2 \mathrm{I} 4$ & I5.6 \\
\hline & Journalism & I9I & 13.9 \\
\hline & Sharia and Law & 218 & I5.9 \\
\hline & Public Administration and Policy & 197 & $\mathrm{I} 4.3$ \\
\hline & Total & $\mathrm{I} 375$ & 100.0 \\
\hline \multirow{5}{*}{$\begin{array}{l}\text { Classes or } \\
\text { Grades }\end{array}$} & Freshman & 460 & 33.5 \\
\hline & Sophomore & 380 & 27.6 \\
\hline & Junior & 310 & 22.5 \\
\hline & Senior & 225 & I6.4 \\
\hline & Total & $\mathrm{I} 375$ & 100.0 \\
\hline \multirow{5}{*}{ Age } & $20-25$ & 1319 & 95.9 \\
\hline & $26-30$ & 35 & 2.5 \\
\hline & $3 I-35$ & 10 & .7 \\
\hline & 36 or Above & II & .8 \\
\hline & Total & 1375 & I00.0 \\
\hline
\end{tabular}

Table I above shows 1375 total participants for the current study. Among them (91.6\%) were male (8.4\%) of them were female. Based on their areas of study, (23.3\%) were from Education faculty, (17.1\%) from language and Literature faculty, (15.6\%) of Law and Political science, (13.9\%) of Journalism, (15.9\%) were studying in Sharia and Law faculty and from (I4.3\%) in the faculty of Public Administration. Regarding the grades of students (33.5\%) freshman, $(27.6 \%)$ sophomore, $(22.5 \%)$ junior and $(16.4 \%)$ senior students made the total number 1375 of the participants. The age of participants (95.9\%) of the respondents were between $29-25,(2.5 \%)$ of the participants were at the age of $26-30,(0.7 \%)$ of the participants were at age of $3 \mathrm{I}-35$, and $(0.8 \%)$ of the participants were either 36 or above that. 
Measuring students' self-confidence in learning process.

The findings of this parts contains the collected data regarding the students' self-confidence level.

Table 2. Students' confidence of getting good grades in their assignments

\begin{tabular}{|c|c|c|c|c|c|c|c|c|c|c|c|}
\hline \multicolumn{2}{|c|}{$\begin{array}{l}\text { Not confident at } \\
\text { all }\end{array}$} & \multicolumn{2}{|c|}{ Less confident } & \multicolumn{2}{|c|}{ Confident } & \multicolumn{2}{|c|}{ More Confident } & \multicolumn{2}{|c|}{$\begin{array}{l}\text { Extremely } \\
\text { confident }\end{array}$} & \multicolumn{2}{|l|}{ Total } \\
\hline $\mathrm{F}$ & $\%$ & $\mathrm{~F}$ & $\%$ & $\mathrm{~F}$ & $\%$ & $\mathrm{~F}$ & $\%$ & $F$ & $\%$ & $\mathrm{~F}$ & $\%$ \\
\hline 16 & I.2 & I I4 & 8.3 & 386 & 28.I & 509 & 37.0 & 350 & 25.5 & 1375 & 100.0 \\
\hline
\end{tabular}

Table 2 above indicates that $25.5 \%$ of students were extremely confident, $37 \%$ students were more confident and $28.1 \%$ students were confident, making up a total of $90.6 \%$ of students who were confident in attaining good grades in their assignments $8.3 \%$ students were less confident and I.2\% students were not confident at all.

Table 3. Students' confidence on performing well in exams

\begin{tabular}{|c|c|c|c|c|c|c|c|c|c|c|c|}
\hline \multicolumn{2}{|c|}{$\begin{array}{l}\text { Not confident at } \\
\text { all }\end{array}$} & \multicolumn{2}{|c|}{ Less confident } & \multicolumn{2}{|c|}{ Confident } & \multicolumn{2}{|c|}{ More Confident } & \multicolumn{2}{|c|}{$\begin{array}{l}\text { Extremely } \\
\text { confident }\end{array}$} & \multicolumn{2}{|l|}{ Total } \\
\hline $\bar{F}$ & $\%$ & $\mathrm{~F}$ & $\%$ & $\mathrm{~F}$ & $\%$ & $\mathrm{~F}$ & $\%$ & $\bar{F}$ & $\%$ & $\mathrm{~F}$ & $\%$ \\
\hline 23 & 1.7 & III & 8.1 & 438 & 31.9 & 535 & 38.9 & 268 & 19.5 & 1375 & I00.0 \\
\hline
\end{tabular}

Table 3 above represent that a total of $90.3 \%$ students were feeling confident performing well in exam, $19.5 \%$ students were extremely confident, $38.9 \%$ students were more confident and 31.9\% students were confident and oppositely $8.1 \%$ students were less confident and I.7\% students were not confident at all.

Table 4. Students' confidence on being well prepared for their upcoming classes

\begin{tabular}{|c|c|c|c|c|c|c|c|c|c|c|c|}
\hline \multicolumn{2}{|c|}{$\begin{array}{l}\text { Not confident at } \\
\text { all }\end{array}$} & \multicolumn{2}{|c|}{ Less confident } & \multicolumn{2}{|c|}{ Confident } & \multicolumn{2}{|c|}{ More Confident } & \multicolumn{2}{|c|}{$\begin{array}{l}\text { Extremely } \\
\text { confident }\end{array}$} & \multicolumn{2}{|l|}{ Total } \\
\hline $\mathrm{F}$ & $\%$ & $\mathrm{~F}$ & $\%$ & $\mathrm{~F}$ & $\%$ & $\mathrm{~F}$ & $\%$ & $\mathrm{~F}$ & $\%$ & $\mathrm{~F}$ & $\%$ \\
\hline $2 \mathrm{I}$ & $\mathrm{I} .5$ & 133 & 9.7 & 372 & 27.1 & 478 & 34.8 & $37 \mathrm{I}$ & 27.0 & 1375 & I00.0 \\
\hline
\end{tabular}

Table 4 above indicates that $27.0 \%$ students were extremely confident, $34.8 \%$ students were more confident and $27.1 \%$ students were confident which makes a total of $88.9 \%$ confident students of being able to be prepared thoroughly for class while $9.7 \%$ students were less confident and I.5\% students were not confident at all in this regard.

Table 5. Students' confidence on having debate with their classmates

\begin{tabular}{|c|c|c|c|c|c|c|c|c|c|c|c|}
\hline \multicolumn{2}{|c|}{$\begin{array}{l}\text { Not confident at } \\
\text { all }\end{array}$} & \multicolumn{2}{|c|}{ Less confident } & \multicolumn{2}{|c|}{ Confident } & \multicolumn{2}{|c|}{ More Confident } & \multicolumn{2}{|c|}{$\begin{array}{l}\text { Extremely } \\
\text { confident }\end{array}$} & \multicolumn{2}{|l|}{ Total } \\
\hline $\mathrm{F}$ & $\%$ & $\mathrm{~F}$ & $\%$ & $\mathrm{~F}$ & $\%$ & $\mathrm{~F}$ & $\%$ & $\mathrm{~F}$ & $\%$ & $\mathrm{~F}$ & $\%$ \\
\hline 35 & 2.5 & 123 & 8.9 & $3 \mathrm{II}$ & 22.6 & 432 & 31.4 & 474 & 34.5 & 1375 & 100.0 \\
\hline
\end{tabular}


Table 5 represents that in regard to students being able to follow the debate with their classmates, majority of students were confident as $34.5 \%$ students were extremely confident, $31.4 \%$ students were more confident and $22.6 \%$ students were confident, making up a total of $88.5 \%$ confident students while only $8.9 \%$ students were less confident and $2.5 \%$ students were not confident at all in this regard.

Table 6 . Students' confidence of being able to understand the materials discussed by the lecturer

\begin{tabular}{|c|c|c|c|c|c|c|c|c|c|c|c|}
\hline \multicolumn{2}{|c|}{$\begin{array}{l}\text { Not confident at } \\
\text { all }\end{array}$} & \multicolumn{2}{|c|}{ Less confident } & \multicolumn{2}{|c|}{ Confident } & \multicolumn{2}{|c|}{ More Confident } & \multicolumn{2}{|c|}{$\begin{array}{l}\text { Extremely } \\
\text { confident }\end{array}$} & \multicolumn{2}{|l|}{ Total } \\
\hline $\mathrm{F}$ & $\%$ & $\mathrm{~F}$ & $\%$ & $\mathrm{~F}$ & $\%$ & $\mathrm{~F}$ & $\%$ & $\mathrm{~F}$ & $\%$ & $\mathrm{~F}$ & $\%$ \\
\hline 35 & 2.5 & I49 & 10.8 & 412 & 30.0 & 486 & 35.3 & 293 & 21.3 & $\mathrm{I} 375$ & I00.0 \\
\hline
\end{tabular}

Table 6 above identity that 21.3\% students were extremely confident, 35.3\% students were more confident and 30\% students were confident however $10.8 \%$ students were less confident and $2.5 \%$ students were not confident at all of being able to understand the materials presented by the lecturer and means that in this regard also most students were highly confident

Table 7. Students' confidence in academic debate with their peers

\begin{tabular}{|c|c|c|c|c|c|c|c|c|c|c|c|}
\hline \multicolumn{2}{|c|}{$\begin{array}{l}\text { Not confident at } \\
\text { all }\end{array}$} & \multicolumn{2}{|c|}{ Less confident } & \multicolumn{2}{|c|}{ Confident } & \multicolumn{2}{|c|}{ More Confident } & \multicolumn{2}{|c|}{$\begin{array}{l}\text { Extremely } \\
\text { confident }\end{array}$} & \multicolumn{2}{|l|}{ Total } \\
\hline $\mathrm{F}$ & $\%$ & $\mathrm{~F}$ & $\%$ & $\mathrm{~F}$ & $\%$ & $\mathrm{~F}$ & $\%$ & $\mathrm{~F}$ & $\%$ & $\mathrm{~F}$ & $\%$ \\
\hline 48 & 3.5 & I 52 & I I.I & 382 & 27.8 & 438 & $3 \mathrm{I} .9$ & 355 & 25.8 & 1375 & 100.0 \\
\hline
\end{tabular}

Table 7 above shows that $25.8 \%$ students were extremely confident, $31.9 \%$ students were more confident and $27.8 \%$ students were confident, making up the total of $85.5 \%$ confident students however II.I\% students were less confident and $3.5 \%$ students were not confident at all of being able to engage in academic debate with their peers and it shows that the majority of students were feeling confident and a small percent of students (in total $14.6 \%$ ) were either lacking confidence or were not confident at all in this regard.

Table 8. Students' confidence in completing the assignment based on required criteria

\begin{tabular}{|c|c|c|c|c|c|c|c|c|c|c|c|}
\hline \multicolumn{2}{|c|}{$\begin{array}{l}\text { Not confident at } \\
\text { all }\end{array}$} & \multicolumn{2}{|c|}{ Less confident } & \multicolumn{2}{|c|}{ Confident } & \multicolumn{2}{|c|}{ More Confident } & \multicolumn{2}{|c|}{$\begin{array}{l}\text { Extremely } \\
\text { confident }\end{array}$} & \multicolumn{2}{|l|}{ Total } \\
\hline $\mathrm{F}$ & $\%$ & $\mathrm{~F}$ & $\%$ & $\mathrm{~F}$ & $\%$ & $\mathrm{~F}$ & $\%$ & $\mathrm{~F}$ & $\%$ & $\mathrm{~F}$ & $\%$ \\
\hline 43 & 3.1 & I56 & I I. 3 & 386 & 28.1 & 454 & 33.0 & 336 & 24.4 & $\mathrm{I} 375$ & I00.0 \\
\hline
\end{tabular}

Table 8 above shows that $24.4 \%$ students were extremely confident, $33.0 \%$ students were more confident and $28.1 \%$ students were confident, making up the total of $85.5 \%$ of confident students and means that majority of the students are highly confident to producing their university works at the required standards while II.3\% students were less confident and $3.1 \%$ students were not confident at all in this regard.

Table 9. Students' confidence in seeking help for unclear concepts.

\begin{tabular}{|c|c|c|c|c|c|c|c|c|c|c|c|}
\hline \multicolumn{2}{|c|}{$\begin{array}{l}\text { Not confident at } \\
\text { all }\end{array}$} & \multicolumn{2}{|c|}{ Less confident } & \multicolumn{2}{|c|}{ Confident } & \multicolumn{2}{|c|}{ More Confident } & \multicolumn{2}{|c|}{$\begin{array}{l}\text { Extremely } \\
\text { confident }\end{array}$} & \multicolumn{2}{|l|}{ Total } \\
\hline $\mathrm{F}$ & $\%$ & $\mathrm{~F}$ & $\%$ & $\mathrm{~F}$ & $\%$ & $F$ & $\%$ & $F$ & $\%$ & $\mathrm{~F}$ & $\%$ \\
\hline 55 & 4.0 & I50 & 10.9 & $35 \mathrm{I}$ & 25.5 & 435 & 31.6 & 384 & 27.9 & 1375 & 100.0 \\
\hline
\end{tabular}


Table 9 shows that students' confident in seeking help from their instructors when they don't understand. Among them $27.9 \%$ were extremely confident, $31.6 \%$ were more confident and $25.5 \%$ were confident which makes up the total $85 \%$ of confident students while just I0.9\% students were less confident and $4 \%$ were not confident in thereof.

Table I0. Students' confidence in giving a presentation to a small group of fellow students or friends.

\begin{tabular}{|c|c|c|c|c|c|c|c|c|c|c|c|}
\hline \multicolumn{2}{|c|}{$\begin{array}{l}\text { Not confident at } \\
\text { all }\end{array}$} & \multicolumn{2}{|c|}{ Less confident } & \multicolumn{2}{|c|}{ Confident } & \multicolumn{2}{|c|}{ More Confident } & \multicolumn{2}{|c|}{$\begin{array}{l}\text { Extremely } \\
\text { confident }\end{array}$} & \multicolumn{2}{|l|}{ Total } \\
\hline $\mathrm{F}$ & $\%$ & $\mathrm{~F}$ & $\%$ & $\mathrm{~F}$ & $\%$ & $\mathrm{~F}$ & $\%$ & $\mathrm{~F}$ & $\%$ & $\mathrm{~F}$ & $\%$ \\
\hline 45 & 3.3 & I 63 & I I.9 & 390 & 28.4 & 400 & 29.I & 377 & 27.4 & 1375 & 100.0 \\
\hline
\end{tabular}

Table IO shows that majority (in total $84.9 \%$ ) of the students were confident in giving presentations to a small group of fellow students or friends. For instance, $27.4 \%$ students were extremely confident, $29.1 \%$ students were more confident $28.4 \%$ students were confident but only II.9\% students were less confident and $3.3 \%$ students were not confident at all in performing this task.

Table II. Students' confidence in seeking help from their lecturers

\begin{tabular}{|c|c|c|c|c|c|c|c|c|c|c|c|}
\hline \multicolumn{2}{|c|}{$\begin{array}{l}\text { Not confident at } \\
\text { all }\end{array}$} & \multicolumn{2}{|c|}{ Less confident } & \multicolumn{2}{|c|}{ Confident } & \multicolumn{2}{|c|}{ More Confident } & \multicolumn{2}{|c|}{$\begin{array}{l}\text { Extremely } \\
\text { confident }\end{array}$} & \multicolumn{2}{|l|}{ Total } \\
\hline $\mathrm{F}$ & $\%$ & $\mathrm{~F}$ & $\%$ & $\mathrm{~F}$ & $\%$ & $\mathrm{~F}$ & $\%$ & $\mathrm{~F}$ & $\%$ & $\mathrm{~F}$ & $\%$ \\
\hline 57 & $4 . \mathrm{I}$ & $\mathrm{I} 58$ & II.5 & 377 & 27.4 & 409 & 29.7 & 374 & 27.2 & $\mathrm{I} 375$ & 100.0 \\
\hline
\end{tabular}

Table II above illustrates that $27.2 \%$ students were extremely confident, $29.7 \%$ students were more confident and $27.4 \%$ students were confident but I I.5\% students were less confident and $4.1 \%$ students were not confident at all in seeking help from their lecturers solutions they have with total $84.3 \%$ of students.

Table I2. Students' confidence in planning appropriate revision schedules for their lessons

\begin{tabular}{|c|c|c|c|c|c|c|c|c|c|c|c|}
\hline \multicolumn{2}{|c|}{$\begin{array}{l}\text { Not confident at } \\
\text { all }\end{array}$} & \multicolumn{2}{|c|}{ Less confident } & \multicolumn{2}{|c|}{ Confident } & \multicolumn{2}{|c|}{ More Confident } & \multicolumn{2}{|c|}{$\begin{array}{l}\text { Extremely } \\
\text { confident }\end{array}$} & \multicolumn{2}{|l|}{ Total } \\
\hline $\mathrm{F}$ & $\%$ & $\mathrm{~F}$ & $\%$ & $\mathrm{~F}$ & $\%$ & $\mathrm{~F}$ & $\%$ & $\mathrm{~F}$ & $\%$ & F & $\%$ \\
\hline 55 & 4.0 & 163 & II.9 & 328 & 23.9 & 429 & 31.2 & 400 & 29.1 & 1375 & 100.0 \\
\hline
\end{tabular}

Table 12 above shows that $29.1 \%$ students were extremely confident, 31.2\% students were more confident and $23.9 \%$ students were confident (in total $84.2 \%$ students were confident) to plan appropriate revision schedules for their lessons but just II.9\% students were less confident and 4\% students were not confident at all to plan a revision schedule for their lessons.

Table 13. Students' confidence in solving exam questions `

\begin{tabular}{|c|c|c|c|c|c|c|c|c|c|c|c|}
\hline \multicolumn{2}{|c|}{ Not confident at all } & \multicolumn{2}{|c|}{ Less confident } & \multicolumn{2}{|c|}{ Confident } & \multicolumn{2}{|c|}{ More Confident } & \multicolumn{2}{|c|}{$\begin{array}{l}\text { Extremely } \\
\text { confident }\end{array}$} & \multicolumn{2}{|l|}{ Total } \\
\hline $\mathrm{F}$ & $\%$ & $\mathrm{~F}$ & $\%$ & $\mathrm{~F}$ & $\%$ & $\mathrm{~F}$ & $\%$ & $\mathrm{~F}$ & $\%$ & $\bar{F}$ & $\%$ \\
\hline 65 & 4.7 & 173 & 12.6 & $40 \mathrm{I}$ & 29.2 & 444 & 32.3 & 292 & 21.2 & 1375 & 100.0 \\
\hline
\end{tabular}


Table 13 above indicates students' confidence in solving exam questions. Among 1375 students, 2I.2\% are extremely confident, $32.3 \%$ are more confident, $29.2 \%$ are confident, $12.6 \%$ are less confident and $4.7 \%$ are not confident at all.

Table I4. Students' confidence in responding to questions asked by the lecturer

\begin{tabular}{|c|c|c|c|c|c|c|c|c|c|c|c|}
\hline \multicolumn{2}{|c|}{ Not confident at all } & \multicolumn{2}{|c|}{ Less confident } & \multicolumn{2}{|c|}{ Confident } & \multicolumn{2}{|c|}{ More Confident } & \multicolumn{2}{|c|}{$\begin{array}{l}\text { Extremely } \\
\text { confident }\end{array}$} & \multicolumn{2}{|l|}{ Total } \\
\hline $\mathrm{F}$ & $\%$ & $\mathrm{~F}$ & $\%$ & $\mathrm{~F}$ & $\%$ & $\bar{F}$ & $\%$ & $\mathrm{~F}$ & $\%$ & $\mathrm{~F}$ & $\%$ \\
\hline $4 \mathrm{I}$ & 3.0 & 213 & $\mathrm{I} 5.5$ & 508 & 36.9 & 369 & 26.8 & 244 & 17.7 & 1375 & 100.0 \\
\hline
\end{tabular}

Table I4 above shows that $17.7 \%$ students were extremely confident, $26.8 \%$ students were more confident and $36.9 \%$ were confident, confident, I5.5\% were less, $3.0 \%$ not confident at all.

Table I5. Students' confidence of being able to manage their workload to meet coursework deadlines

\begin{tabular}{|c|c|c|c|c|c|c|c|c|c|c|c|}
\hline \multicolumn{2}{|c|}{$\begin{array}{l}\text { Not confident at } \\
\text { all }\end{array}$} & \multicolumn{2}{|c|}{ Less confident } & \multicolumn{2}{|c|}{ Confident } & \multicolumn{2}{|c|}{ More Confident } & \multicolumn{2}{|c|}{$\begin{array}{l}\text { Extremely } \\
\text { confident }\end{array}$} & \multicolumn{2}{|l|}{ Total } \\
\hline $\mathrm{F}$ & $\%$ & $\mathrm{~F}$ & $\%$ & $\mathrm{~F}$ & $\%$ & $\mathrm{~F}$ & $\%$ & $\mathrm{~F}$ & $\%$ & $\mathrm{~F}$ & $\%$ \\
\hline $7 \mathrm{I}$ & 5.2 & 319 & 23.2 & 474 & 34.5 & 325 & 23.6 & I 86 & 13.5 & 1375 & I00.0 \\
\hline
\end{tabular}

Table 15 above represents that majority (in total 7I.6\%) of the students were confident in managing their workload to meet the course work deadlines as $13.5 \%$ students were extremely confident, $23.6 \%$ students were more confident and $34.5 \%$ students were confident but $23.2 \%$ students were less confident and $5.2 \%$ students were not confident at all.

Table 16. Students' confidence in studying effectively independently

\begin{tabular}{llllllllllll}
\hline $\begin{array}{l}\text { Not confident at } \\
\text { all }\end{array}$ & \multicolumn{2}{l}{ Less confident } & Confident & More Confident & $\begin{array}{l}\text { Extremely } \\
\text { confident }\end{array}$ & & Total \\
\hline F & $\%$ & F & $\%$ & F & $\%$ & F & $\%$ & F & $\%$ & F & $\%$ \\
54 & 3.9 & 235 & I7.I & 462 & 33.6 & 404 & 29.4 & 220 & I6.0 & I375 & I00.0 \\
\hline
\end{tabular}

Table I6 above represent students' confidence in studying effectively independently. Among I375 respondents, I6\% were extremely confident, $29.4 \%$ were more confident and $33.6 \%$ were $17.1 \%$ were less confident and $3.9 \%$ were not confident at.

The effects of students' self-confidence on their learning process

The data was collected to find out the effect students' self-confidence on their learning process.

Table 17. Students' confidence can make students more interested toward goal seeking

\begin{tabular}{llllllllllll}
\hline \multicolumn{2}{c}{ Strongly disagree } & \multicolumn{2}{l}{ Disagree } & \multicolumn{2}{c}{ Undecided } & \multicolumn{2}{c}{ Agree } & \multicolumn{3}{c}{ Strongly agree } & \multicolumn{2}{c}{ Total } \\
\hline F & $\%$ & F & $\%$ & F & $\%$ & F & $\%$ & F & $\%$ & F & $\%$ \\
22 & I.6 & 58 & 4.2 & II5 & 8.4 & 535 & 38.9 & 645 & 46.9 & 1375 & 100.0 \\
\hline
\end{tabular}


Table 17 above illustrates that most (in total 85.8\%) of the students agreed that confidence can make learners interested toward goal seeking since $46.9 \%$ students strongly agreed, $38.9 \%$ students agreed, $8.4 \%$ students were undecided, $4.2 \%$ students disagreed and I.6 students strongly disagreed.

Table I8. Student's confidence can cause them to make a regular plan for reviewing their lessons

\begin{tabular}{|c|c|c|c|c|c|c|c|c|c|c|c|}
\hline \multicolumn{2}{|c|}{ Strongly disagree } & \multicolumn{2}{|c|}{ Disagree } & \multicolumn{2}{|c|}{ Undecided } & \multicolumn{2}{|c|}{ Agree } & \multicolumn{2}{|c|}{ Strongly agree } & \multicolumn{2}{|l|}{ Total } \\
\hline F & $\%$ & $\mathrm{~F}$ & $\%$ & $\mathrm{~F}$ & $\%$ & $\mathrm{~F}$ & $\%$ & $\mathrm{~F}$ & $\%$ & $\mathrm{~F}$ & $\%$ \\
\hline 26 & I.9 & $7 \mathrm{I}$ & 5.2 & I I5 & 8.4 & 595 & 43.3 & 568 & 41.3 & $\mathrm{I} 375$ & 100.0 \\
\hline
\end{tabular}

Table 18 above indicates that $41.3 \%$ students strongly agreed, $43.3 \%$ students agreed that confidence can cause them to make regular plan for reviewing their lessons however $8.4 \%$ students were undecided, 5.2\% students disagreed and $1.9 \%$ students strongly disagreed. And the total percent of agree student is $84.6 \%$ which shows that most of the students agreed to this regard.

Table 19. Student's confidence can cause students to confidentially give their opinions in discussions

\begin{tabular}{llllllllllll}
\hline \multicolumn{2}{l}{ Strongly disagree } & \multicolumn{2}{l}{ Disagree } & \multicolumn{2}{l}{ Undecided } & \multicolumn{2}{c}{ Agree } & \multicolumn{3}{c}{ Strongly agree } & \multicolumn{2}{c}{ Total } \\
\hline F & $\%$ & F & $\%$ & F & $\%$ & F & $\%$ & F & $\%$ & F & $\%$ \\
30 & 2.2 & 69 & 5.0 & I I4 & 8.3 & 666 & 48.4 & 496 & 36.1 & I375 & I00.0 \\
\hline
\end{tabular}

Table 19 above indicates $s$ that majority of students (84.5\%) students agreed that confidence cause them confidentially give their opinions regarding the lesson as: $36.1 \%$ students strongly agreed and $48.4 \%$ students agreed, $8.3 \%$ students were undecided, $5 \%$ students disagreed and $2.2 \%$ students strongly disagreed in this regard.

Table 20. Student's confidence can cause students being active in class participation

\begin{tabular}{|c|c|c|c|c|c|c|c|c|c|c|c|}
\hline \multicolumn{2}{|c|}{ Strongly disagree } & \multicolumn{2}{|c|}{ Disagree } & \multicolumn{2}{|c|}{ Undecided } & \multicolumn{2}{|c|}{ Agree } & \multicolumn{2}{|c|}{ Strongly agree } & \multicolumn{2}{|l|}{ Total } \\
\hline $\mathrm{F}$ & $\%$ & $\mathrm{~F}$ & $\%$ & $\mathrm{~F}$ & $\%$ & $\mathrm{~F}$ & $\%$ & $\mathrm{~F}$ & $\%$ & $\mathrm{~F}$ & $\%$ \\
\hline 36 & 2.6 & 65 & 4.7 & 72 & 5.2 & 657 & 47.8 & 545 & 39.6 & 1375 & 100.0 \\
\hline
\end{tabular}

Table 20 above represents that majority of students (84.4\% students) agreed that confidence can cause them to have more class participation since $39.6 \%$ students strongly agreed $47.8 \%$ students agreed, $5.2 \%$ students were undecided, $4.7 \%$ students disagreed and $2.6 \%$ students strongly disagreed to the statement "Students' confidence can cause students have more class participation."

Table 2I. Student's confidence can cause students have good presentation

\begin{tabular}{llllllllllll}
\hline \multicolumn{2}{c}{ Strongly disagree } & \multicolumn{2}{l}{ Disagree } & \multicolumn{2}{l}{ Undecided } & Agree & \multicolumn{3}{c}{ Strongly agree } & \multicolumn{2}{c}{ Total } \\
\hline F & $\%$ & F & $\%$ & F & $\%$ & F & $\%$ & F & $\%$ & F & $\%$ \\
26 & I.9 & 78 & 5.7 & IIO & 8.0 & 632 & 46.0 & 529 & 38.5 & I375 & 100.0 \\
\hline
\end{tabular}

Table $2 \mathrm{I}$ above shows that $38.5 \%$ of the respondents agreed that self-confidence helps students give good presentation. In addition, $46.0 \%$ students agreed, $8.0 \%$ students were undecided, $5.7 \%$ students disagreed and $1.9 \%$ students strongly disagreed. 
Table 22. Student's confidence can help them doing their assignments based on required

\begin{tabular}{llllllllllll}
\hline \multicolumn{2}{l}{ Strongly disagree } & \multicolumn{2}{l}{ Disagree } & \multicolumn{2}{l}{ Undecided } & \multicolumn{2}{l}{ Agree } & \multicolumn{3}{c}{ Strongly agree } & \multicolumn{2}{c}{ Total } \\
\hline F & $\%$ & F & $\%$ & F & $\%$ & F & $\%$ & F & $\%$ & F & $\%$ \\
24 & I.7 & 78 & 5.7 & I 27 & 9.2 & 662 & 48.1 & 484 & 35.2 & I375 & 100.0 \\
\hline
\end{tabular}

Table 22 above represents majority of students agreed that confidence helps them doing their assignments based on required standards as $35.2 \%$ students strongly agreed and $48.1 \%$ students agreed but $9.2 \%$ students were undecided, $5.7 \%$ students disagreed and $1.7 \%$ students strongly disagreed with this statement.

Table 23. Student's confidence can cause them in asking questions confidentially related to their lessons from their classmates

\begin{tabular}{|c|c|c|c|c|c|c|c|c|c|c|c|}
\hline \multicolumn{2}{|c|}{ Strongly disagree } & \multicolumn{2}{|c|}{ Disagree } & \multicolumn{2}{|c|}{ Undecided } & \multicolumn{2}{|c|}{ Agree } & \multicolumn{2}{|c|}{ Strongly agree } & \multicolumn{2}{|l|}{ Total } \\
\hline $\mathrm{F}$ & $\%$ & $\mathrm{~F}$ & $\%$ & $\mathrm{~F}$ & $\%$ & $\mathrm{~F}$ & $\%$ & $\mathrm{~F}$ & $\%$ & $\mathrm{~F}$ & $\%$ \\
\hline 32 & 2.3 & 81 & 5.9 & 99 & 7.2 & 544 & 39.6 & 619 & 45.0 & 1375 & $\mathrm{I} 00.0$ \\
\hline
\end{tabular}

Table 23 above indicates that majority of the students agreed that confidence can cause students confidentially ask lesson related questions from their classmates. $45 \%$ students strongly agree $39.6 \%$ students agreed: the two combined made the $84.6 \%$ agreed students and just $7.2 \%$ students were undecided, $5.9 \%$ students disagreed and $2.3 \%$ students strongly disagreed.

Table 24. Student's confidence can make the lesson more enjoyable to the students

\begin{tabular}{llllllllllll}
\hline \multicolumn{2}{l}{ Strongly disagree } & \multicolumn{2}{l}{ Disagree } & \multicolumn{2}{c}{ Undecided } & \multicolumn{2}{c}{ Agree } & \multicolumn{3}{c}{ Strongly agree } & \multicolumn{2}{c}{ Total } \\
\hline F & $\%$ & F & $\%$ & F & $\%$ & F & $\%$ & F & $\%$ & F & $\%$ \\
40 & 2.9 & 76 & 5.5 & I20 & 8.7 & 617 & 44.9 & 522 & 38.0 & 1375 & 100.0 \\
\hline
\end{tabular}

Table 24 below indicates that most of the students $82.9 \%$ agreed that self-confidence can make the lesson more enjoyable to them as $38 \%$ students strongly agreed $44.9 \%$ students agreed, $8.7 \%$ students were undecided, $5.5 \%$ students disagreed and $2.9 \%$ students strongly disagreed with the statement.

Table 25. Student's confidence can cause students to confidentially ask lesson related question from their lecturers.

\begin{tabular}{|c|c|c|c|c|c|c|c|c|c|c|c|}
\hline \multicolumn{2}{|c|}{ Strongly disagree } & \multicolumn{2}{|c|}{ Disagree } & \multicolumn{2}{|c|}{ Undecided } & \multicolumn{2}{|c|}{ Agree } & \multicolumn{2}{|c|}{ Strongly agree } & \multicolumn{2}{|l|}{ Total } \\
\hline $\mathrm{F}$ & $\%$ & $\mathrm{~F}$ & $\%$ & $\mathrm{~F}$ & $\%$ & $\mathrm{~F}$ & $\%$ & $\mathrm{~F}$ & $\%$ & $\mathrm{~F}$ & $\%$ \\
\hline 33 & 2.4 & II5 & 8.4 & 79 & 5.7 & 630 & 45.8 & 518 & 37.7 & 1375 & 100.0 \\
\hline
\end{tabular}

Table 25 above illustrates that majority of the students (83.5\% students) agreed that confidence can cause students confidentially ask lesson related questions from their lecturers as $37.7 \%$ students strongly agreed, $45.8 \%$ students agreed but $5.7 \%$ students were undecided, $8.4 \%$ students disagreed and $2.4 \%$ students strongly disagreed in this regard. 
Table 26. Student's confidence can cause students have less anxiety about exam and do better in exams

\begin{tabular}{|c|c|c|c|c|c|c|c|c|c|c|c|}
\hline \multicolumn{2}{|c|}{ Strongly disagree } & \multicolumn{2}{|c|}{ Disagree } & \multicolumn{2}{|c|}{ Undecided } & \multicolumn{2}{|c|}{ Agree } & \multicolumn{2}{|c|}{ Strongly agree } & \multicolumn{2}{|l|}{ Total } \\
\hline $\mathrm{F}$ & $\%$ & $\mathrm{~F}$ & $\%$ & $\bar{F}$ & $\%$ & $\mathrm{~F}$ & $\%$ & $\mathrm{~F}$ & $\%$ & F & $\%$ \\
\hline $4 \mathrm{I}$ & 3.0 & I IO & 8.0 & 136 & 9.9 & 617 & 44.9 & $47 \mathrm{I}$ & 34.3 & 1375 & 100.0 \\
\hline
\end{tabular}

Table 26 above shows that in total 79.2 percent or more than a half of students agreed that confidence decreases students' anxiety in exam and can cause students do better in exams, on the other hand, 34.3\% of students strongly agreed, 44.9\% students agreed, $9.9 \%$ students were undecided, $8 \%$ students disagreed and $3 \%$ students strongly disagreed.

Table 27. Student's confidence can cause students work and learn more independently

\begin{tabular}{|c|c|c|c|c|c|c|c|c|c|c|c|}
\hline \multicolumn{2}{|c|}{ Strongly disagree } & \multicolumn{2}{|c|}{ Disagree } & \multicolumn{2}{|c|}{ Undecided } & \multicolumn{2}{|c|}{ Agree } & \multicolumn{2}{|c|}{ Strongly agree } & \multicolumn{2}{|l|}{ Total } \\
\hline $\mathrm{F}$ & $\%$ & $F$ & $\%$ & $F$ & $\%$ & $F$ & $\%$ & $F$ & $\%$ & $F$ & $\%$ \\
\hline 38 & 2.8 & II5 & 8.4 & I I4 & 8.3 & 613 & 44.6 & 495 & 36.0 & 1375 & I00.0 \\
\hline
\end{tabular}

Table 27 above revealed that 36\% students strongly agreed, $44.6 \%$ students agreed, $8.3 \%$ students were undecided, $8.4 \%$ students disagreed and $2.8 \%$ students strongly disagreed that confidence enhances students' independent working and learning. The total percent of agreed students is $80.6 \%$ which shows that most of the students agreed in this regard.

Table 28. Student's confidence can make students to computer and internet easier for their academic purposes

\begin{tabular}{cccccccccccc}
\hline Strongly disagree & Disagree & \multicolumn{3}{c}{ Undecided } & \multicolumn{2}{c}{ Agree } & \multicolumn{3}{c}{ Strongly agree } & \multicolumn{2}{c}{ Total } \\
\hline F & $\%$ & F & $\%$ & F & $\%$ & F & $\%$ & F & $\%$ & F & $\%$ \\
73 & 5.3 & IOI & 7.3 & I 49 & 10.8 & 499 & 36.3 & 553 & 40.2 & 1375 & 100.0 \\
\hline
\end{tabular}

Table 28 shows that most of the students (76.5\%) agreed that confidence makes the use of computer and internet easier for students' academic purposes as: $40.2 \%$ students strongly agreed, $36.3 \%$ students agreed and I0.8\% students were undecided, $7.3 \%$ students disagreed and $5.3 \%$ students strongly disagreed in this regard.

\section{Discussion}

The findings of this study show that majority of students at Kandahar University are highly self-confident in performing several tasks in the class or out of the class, but still there are less students who have low self-confidence in their performance. It is also revealed that students' self-confidence is very effective in learning process and had positive impacts in their learning process. The finding of this study is similar to the findings of Mahyuddin et.al(2006) where more than a half of students were confident in learning and less than a half of the students were low confident in learning. In regards of students' confidence in being able to study independently, I6\% of students were extremely confident, $29.4 \%$ of students were more confident, $33.6 \%$ of students were confident, $17.1 \%$ of students were less confident and $3.9 \%$ of students were not confident at all and self-confidence was an effective factor on students learning.

The findings of this study in regards of self- confidence can improve participation is in line with Norman \& Hyland (2003); Yashima, Zenuk-Nishide, \& Shimizu (2004) findings. The study revealed that 39.6\% of the students strongly agreed and $47.8 \%$ of the students agreed in this regard. On the other hand, the finding of this study is in apposite with Puzziferro (2008) findings who assert that confidence in online technology is not related to students' performance while this study revealed that $76.5 \%$ of students either strongly agreed or agreed that confidence can cause students to use the computer and internet easier for academic purposes. The findings of this study confirmed the finding of Jones (200I) that indicated $46.9 \%$ of the students strongly agreed and $38.9 \%$ of the students agreed for self-confidence have on students' interest towards goal seeking.

The main implication derived from the study in general refers to all university teachers and specially to Kandahar University teachers to use present study's findings showing that more than a half of students at Kandahar University were highly self- 
confident but still a small percentage of students at Kandahar University were low self-confident. Therefore, the researcher considers it necessary for academic staff of Kandahar University to pay special attention to students who have low selfconfidence by helping them to develop self-confidence for the findings of current study showed that self-confidence has many positive impacts on students learning and performance inside and outside the class.

\section{I0. Conclusion}

The findings of this study revealed that the level of students' self-confidence in learning in various areas. It showed that students in some areas of learning have low self-confidence. On the other hands majority of them were highly self-confident. The study also found out the impacts of students' self-confidence in learning process at Kandahar University. for instance, the study found out that students 'with self-confidence can lead them improved participation, enjoy learning, reduced test anxiety, increased interest in goal seeking, growth of comfort with their lecturers and classmates and finally help them in sharing their experience and opinions in the class.

\section{References}

Afzal, H., Ali, I., Aslam Khan, M., \& Hamid, K. (2010). A study of university students' motivation and its relationship with their academic performance. International Journal of Business and Management, 5 (4), 80-88.

Atherton, M. (2015). Measuring confidence levels of male and female students in open access enabling courses. Issues in Educational Research, 25(2), 8I-98.

Bauman, S. (2012). The importance of self-esteem in learning and behavior in children with exceptionalities and the role magic tricks may play in improving self-esteem and in motivating learning (Thesis of partial completion at college). http://stars.library.ucf.edu/honorstheses I990-20I5/I344?utm_source=stars.library.ucf.edu\%2FhonorsthesesI9902015\%2FI344\&utm_medium=PDF\&utm_campaign=PDFCoverPages

Benabou, R., \& Tirole, J. (2002). Self-confidence and personal motivation. The Quarterly Journal of Economics, II 7(3), 87 I915.

Busch, T. (1995). Gender differences in self-efficacy and attitudes toward computers. Journal of educational computing research, I2(2), I47-I58.

Chemers, M. M., Hu, L. T., \& Garcia, B. F. (200I). Academic self-efficacy and first year college student performance and adjustment. Journal of Educational psychology, 93(I), 55.

Clark, J., \& Barber, B. L. (I994). Adolescents in postdivorce and always-married families: Self-esteem and perceptions of fathers' interest. Journal of Marriage and the Family, 608-6I4.

Colbeck, C. L., Cabrera, A. F., \& Terenzini, P. T. (200I). Learning professional confidence: Linking teaching practices, students' self-perceptions, and gender. The Review of Higher Education, 24(2), I73-I9I.

Creswell, J. W. (2012). Educational research: planning, Conducting, and Evaluating (4 ${ }^{\text {th }}$ ed.). Boylston Street, Boston: Pearson Education.

De Houwer, J., Barnes-Holmes, D., \& Moors, A. (2013). What is learning? On the nature and merits of a functional definition of learning. Psychonomic Bulletin \& Review, 20(4), 63I-642.

Djehiche, K. (2016). The Importance of Self-confidence in Enhancing Students' Speaking Skill Case study: First Year LMD Students at Mohammad Kheider University of Biskra (Doctoral dissertation).

Fatma, F. (2015). A study of self-confidence of adolescents in relation to their gender, locality and academic achievement. IJAR, I(I2), 54I-544.

Fischer, M., \& Sliwka, D. (2018). Confidence in knowledge or confidence in the ability to learn: An experiment on the causal effects of beliefs on motivation. Games and Economic Behavior, III, I22-I42.

Gardner, D. G., Dukes, R. L., \& Discenza, R. (1993). Computer use, self-confidence, and attitudes: A causal analysis. Computers in human behavior, $9(4), 427-440$.

Jakobsson, A. (2006). Students' self-confidence and learning through dialogues in a net-based environment. Journal of Technology and Teacher Education, I4(2), 387-405.

Jones, H. K. (200I). Academic Self-Confidence Scale: A Psychological Study in Two Parts. University of Tennessee Honors Thesis Projects s. http://trace.tennessee.edu/utk_chanhonoproj/472.

Karimi, A., \& Saadatmand, Z. (20I4). The relationship between self-confidence with achievement based on academic motivation. Kuwait Chapter of Arabian Journal of Business and Management Review, 33(2579), 210-2I5.

Laird, T. F. N. (2005). College students' experiences with diversity and their effects on academic self-confidence, social agency, and disposition toward critical thinking. Research in higher education, 46(4), 365-387.

Mahyuddin, R., Elias, H., Cheong, L. S., Muhamad, M. F., Noordin, N., \& Abdullah, M. C. (2006). The relationship between students' self-efficacy and their English language achievement. Jurnal Pendidik dan Pendidikan, Jil, 2I, 6I-7I.

Norman, M., \& Hyland, T. (2003). The role of confidence in lifelong learning. Educational studies, 29(2-3), $26 \mathrm{I}-272$. 
Nurmi, A., Hannula, M., Maijala, H., \& Pehkonen, E. (2003). On Pupils' Self-Confidence in Mathematics: Gender Comparisons. International Group for the Psychology of Mathematics Education, 3, 453-460.

Pajares, F., \& Johnson, M. J. (I994). Confidence and competence in writing: The role of self-efficacy, outcome expectancy, and apprehension. Research in the Teaching of English, 3I3-33I.

Palavan, Ö. (2017). Impact of Drama Education on The Self-Confidence and Problem-Solving Skills of students of Primary School Education. Kastamonu Education Journal, 25(I).

Perkins, K. E. (2018). The Integrated Model of Self-Confidence: Defining and Operationalizing Self-Confidence in Organizational Settings (Doctoral dissertation). College of Psychology and Liberal Arts: Florida Institute of Technology, Melbourne, Florida.

Prada Arango, H. (2015). Students' self-confidence as a way to improve English oral Production in IOth grade students at Ricaurte school. (Mastering research project). University of Libre, Bogota.

Pulford, B. D., \& Sohal, H. (2006). The influence of personality on HE students' confidence in their academic abilities. Personality and Individual Differences, 4I(8), I409-I4I9.

Puzziferro, Maria. "Online technologies self-efficacy and self-regulated learning as predictors of final grade and satisfaction in college-level online courses." The Amer. Jrnl. of Distance Education 22, no. 2 (2008): 72-89.

Rubio, R. A. (2007). Self-esteem and foreign language learning. Cambridge Scholars Publishing. I5 Angerton Gardens, Newcastle: Cambridge Scholars Publishing.

Sander, P., \& Sanders, L. (2003). Measuring confidence in academic study: a summary report. University of Wales Institute: Cardiff U. K.

Şar, A. H., Avcu, R., \& Işıklar, A. (20I0). Analyzing undergraduate students' self-confidence levels in terms of some variables. Procedia-Social and Behavioral Sciences, 5, I205-I209.

Sihotang, L., Setiawan, D. \& Saragi, D. (2017). The Effect of Learning Strategy and Self -Confidence Toward Student's Learning Outcomes in Elementary School. IOSR Joumal of Research \& Method in Education. 7(4), 65-72.

Taylor, G. R., \& MacKenney, L. (2008). Improving human learning in the classroom: Theories and teaching practices. R\&L Education.

Tridinanti, G. (20I8). The Correlation between Speaking Anxiety, Self-Confidence, and Speaking Achievement of Undergraduate EFL Students of Private University in Palembang. International Journal of Education and Literacy Studies, 6(4), 35-39.

Tripathy, M., \& Srivastava, S. K. (2012). To Study the Effect of Academic Achievement on the Level of Selfconfidence. International Journal of Yoga and Allied Sciences, I(I), 33-45.

Tunçel, H. (20I5). The Relationship between Self-Confidence and Learning Turkish as a Foreign Language. Educational Research and Reviews, IO(I8), 2575-2589.

Verma, R. K., \& Kumari, S., (2016). Effect of Self-Confidence on Academic Achievement of Children at Elementary Stage. Indian Journal of Reseach, 5(I) 8I-83.

Wright, J. H. (2009). Building Self-confidence with Encouraging Words. West Central, Missoula: Artichoke Press.

Yashima, T., Zenuk-Nishide, L., \& Shimizu, K. (2004). The influence of attitudes and affect on willingness to communicate and second language communication. Language learning, 54(I), II9-I52.

\section{Copyrights}

Copyright for this article is retained by the author(s), with first publication rights granted to the journal. This is an open-access article distributed under the terms and conditions of the Creative Commons Attribution license (http://creativecommons.org/licenses/by/4.0/). 